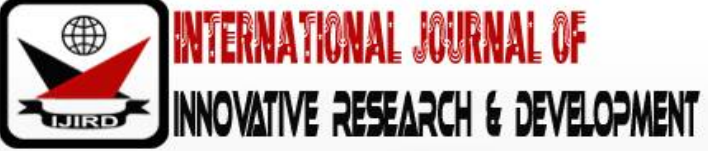

ISSN 2278 - 0211 (Online)

\section{A Survey of Sports Tourism Facilities in JOS Nigeria}

\author{
Gonap Elisha Gobin \\ Lecturer, Department of Hospitality and Tourism Management, \\ Federal University Wukari, Nigeria \\ Ogoina Hembafan Pius \\ Ph.D. Scholar, Department of Archaeology and Tourism, \\ University of Nigeria Nsukka, Nigeria \\ Nalkap Turfa \\ Graduate Assistant, Department of Hospitality and Tourism Management, \\ Federal University Wukari, Nigeria
}

\begin{abstract}
:
Tourism, if properly developed has the ability to boost the economy of the host destination through income generation and job creation. This study assessed the availability of sport-tourism facilities in Jos metropolis, Plateau State, Nigeria. A set of questionnaires was the major instrument used for data collection. The selected data collection centers within the study area included the Rwang-Pam Township Stadium, Plateau Club, Laming Golf Course, University of Jos and Bukuru Mini Stadium. Data were presented in tables and summarized in percentages. Results showed that there are thirty-three (33) sport facilities in the study area which are unevenly distributed across the data collection points with football being the most common, while a total of seventy-nine (79) additional sports facilities are required with gymnasium and taekwondo leading. The study suggests the need to fully develop sport-tourism facilities so as to boost the internally generated revenue and foreign exchange.
\end{abstract}

Keywords: Sport, tourism, sport-tourism, internally generated revenue, foreign exchange

\section{Introduction}

The origin of sport is as old as that of mankind. As a result, it is difficult to state with precession when, where and how sports became part of man's life. A look at the history of sports suggests that different forms of contemporary sports would have originated from different parts of the world at different time. This is because since the early times, sports like walking, wrestling and dancing as well as other traditional games played very important roles in the life of the prehistoric man, although they have been looked upon with disapproval by certain groups (Gibson 1998a).

Sport is now regarded by many to be the world's biggest social phenomenon (Kurtzman \& Zauhar, 2003) and tourism its largest industry (Standeven \& Deknop, 1999). Sport and tourism are believed to be among the world's most popular leisure experiences (Ritchie \& Adair, 2004). The major sporting events contribute significantly to the economic development and tourist traffic in a city or region and are a vital component of the marketing mix for tourist destinations (Getz, 1998). Sport tourism is defined as "all forms of active and passive involvement in sporting activity, participated in casually or in an organized way for non-commercial or business/commercial reasons that necessitate travel away from home and work locality" (Standevan \& Deknop, 1999, p. 12). Gibson (1998) defined sport tourism as "leisure-based travel that takes individuals temporarily outside of their home communities to participate in physical activities, to watch physical activities, or to venerate attractions associated with physical activities".

In Nigeria, the earliest forms of sports were traditional or culturally-oriented and primitive. During the colonial period, however some sporting activities/ facilities were introduced. These included mainly golf, card games, athletics and excursions which were popular, but limited largely to the well-to-do and the colonial masters (Gonap et al., 2017).Early sports in Nigeria cannot be stated with precision because of the poor historical documentation, lack of substantial archaeological evidence as well as series of events which marked the distinctive stages of periods of man civilization. Sports tourism is one of the fastest growing sectors in the tourism industry, accounting for about 10\% of the worlds gross domestic product with an attendant increase in participants each year amongst countries that have played host to international sporting festivals. (UNWTO2018). Unfortunately, Nigeria has not benefited maximally from sports tourism due to various factors militating against tourism in Nigeria, ranging from insecurity, to lack of tourism facilities amongst others. This work examined the availability of sporting facilities in Jos Nigeria.

Backman (1995): defines sport as "an activity pursued during leisure time, either as an individual or collectively, that is free and pleasurable, having its own immediate appeal, not impelled by a delayed reward beyond itself. The international study group on leisure and social science defines sport as "a number of occupations in which the individual may indulge his own freewill either to rest, to amuse himself, to add his knowledge and improve his skills disinterested 
and to increase his voluntarily participation in the life of the community after discharging his professional, family and social duties." Some examples are football, tennis, golf, surfing, water sport (swimming, yachting) Racing (car, bicycle, horse and motor cycling).According to Kambayari (2012), sport is a formidable instrument for nation building, unity, youth empowerment and behavior modification as well as veritable tool for promotion of sports economy, tourism and recreation. Sport fosters peace, unity and above all sustained development of human capacity.

Chibuikem (2011), describes tourism is the discretional movement of people from their normal places of residence to where they are strangers and where their activities in the new places of visit do not involve any money earning activities. Such a movement is however for a relatively short period of time and the purpose may include leisure, interpersonal business, religious, medical and meetings. Sports tourismtherefore, refers to travel which involves either viewing or participating in a sporting event staying apart from their usual environment. Sport tourism is a fast-growing sector of the global travel industry and equates to $\$ 600$ billion a year.

Sports Tourism according to UNWTO is the movement of person(s) away from his or her original place of residence for the purpose of experiencing sports and whose period of stay at the destination is not less than 24hours, not permanent in nature and not connected to earning purpose (Gonap et al., 2017).

The first scientific publication with the theme sports tourism: The Journal of Sports Tourism, appeared in 1983 and the first world conference on the topic was organized jointly by the United Nations World Tourism Organization (UNWTO) and the Comity International Olympique (CIO) 2001. The discussion gained in recent years took into account the relationships between tourism and sport and integrated elements of sports (for example the motor experience) and elements of tourism (travel culture). The behaviors that are observed are sport characterized by social activities of various kinds, both physical and cultural.

Nigeria is endowed with numerous tourism potentials. However, most of these potentials are either totally neglected or partially developed. According to Ryal-Net (2010) tourism represents the biggest and undoubtedly the most diverse and creative economic activity of all. It's a form of development, a multi-sectorial activity that has social, educational, cultural and economic values that requires strategic planning at all levels. Inadequate planning in tourism sector, leads to decay tourism potentials in Nigeria.

Gammon (2003) claims that around a quarter of all holidays have sport as the primary purpose of the trip with nearly $50 \%$ of domestic holidays including some form of participation in sport. Over the years, the desire of successive leaders to move the Nigerian economy to an enviable level had been hampered by the country's problematic monoeconomy and overdependence on revenue from oil. The situation has been made worse by fears that the oil would dry up someday. To proffer solution to this challenge, the tourism sector has been identified as a viable and sustainable income generatorif given the desired attention by government at all levels. The Nigeria Tourism Development Corporation (NTDC) believes that while oil is exhaustible, tourism is sustainable.

A study by the European Tour Operator Association (ETOA) further analyzed the impact of the games on the city and found that tourism now accounts for 12\% of the city's GDP, compared to 1-2\% before the Olympics Mason (2008). Overnight stays in Barcelona in the build up to the games, the city increased its hotel bed capacity by $34.9 \%$, which has continued many years after the event. The ETOA European Tour Operator Association found that between 1992 and 2002, 75 additional hotels were built in the city, which resulted in a further bed space expansion of $47 \%$. This provided the city with a platform to increase overnight stay in the city by $110 \%$ between 1990 and 2001.

Other studies on evaluation of various touristic potentials have been carried out and theycut across various features such as waterfalls, rivers capes ponds and wild life reserves Plateau State (2005) However, none of these studies assessed the availability of sport tourism facilities in Jos Metropolis. This particular research aimed at surveying sports tourism facilities in Jos Metropolis.

\subsection{The Study Area}

Jos, the study area is divided into three (3) Local Government Areas of Jos North, Jos South and Jos East. The city has formed an agglomeration with the town of Bukuru to form the Jos-Bukuru Metropolis with the altitude of $1,217 \mathrm{~m}$ (4062 feet) above sea level. It enjoys more temperate climate than most of the rest of Nigeria average monthly temperature ranges from $21^{\circ} \mathrm{C}$ to $25^{\circ} \mathrm{C}$ ). According to Getz (1998) from mid-November to late January, night time temperatures drop as low as $11^{\circ} \mathrm{C}$ resulting in chilling nights. Jos is a favorite holiday location for both tourists and expatriates based in Nigeria situated almost at the geographical Centre of Nigeria and about 300Km (109miles) from Abuja the nation's capital.

Jos has a lot of tourism sites such as Kahwang Basalt Rock Formation, the Share Hills (this is a range of hills and rock formation with the highest point standing at about 1,829 metres above sea level), The Wase Rock(a massive that stands at a height of 350 metres above sea level), the Kiwi Conical Hill in BarkinLadi, Riyom, rock formation(surrounding by many other rock formations) and the Bal Hill Katvi in Mangu. The state also boasts of a dormant volcano known as Karang volcano which is also situated in Mangu, home to the popular SWAN water. There are parks and zoo in the study area such as the Jos Wildlife Park and Zoo, Pandam Game Reserve and Wase Rock Game Reserve. Some of the animals found there include; lions, elephants, hyenas, buffalos, derby elands, red river hogs Nile crocodiles, chimpanzees, and pigmy hippopotamus. The birds that are predominant in the state include ostrich, bateleur eagle, twang eagles, pea fowl king reed hens and peacock.

Unique parks and gardens contribute to the aesthetic landscape of plateau state. Some of this includes Solomon Lar Amusement park, Nigeria Tobacco company Garden, Zuzi Garden, Gray Garden, labour crescent garden, Jos Wildlife Park and also museum garden. The state also has a variety of hotels to the delight of tourists. Some of the Hotels include Plateau Hotel, Hotel De Maria Mountain Green Hotel, New Jos Hotel, Hilltop Hotel and Metro Hotel. Similarly, the Ray field 
holiday resort, located four kilometers from Jos city offers tourists endless fun of boating, sun bathing, horse riding, sport finishing and indoor games.

\section{Materials and Methods}

The aim of this study is to assess the sport-tourism facilities in Jos Nigeria. To achieve this aim, data was collected from different sporting centers within Jos metropolis. The primary data for this research was sourced from sporting centers namely; Rwang-Pam Township Stadium, Plateau Club, Laming Golf Course, University of Jos and Bukuru Mini Stadium. A well-structured questionnaire was distributed to 200 respondents purposefully selected from the participants at the sporting centers that constituted the study population for this survey after a general reconnaissance and other previous visits and pretest were also carried out. Two hundred (200) respondents filled and returned the survey questionnaire. In selecting the sports men and women (sport-tourists), availability sampling method was used, that is selecting sport-tourists that were found at the various centers that had attained 18 years and above. The researchers at each center took inventory of facilities and then administered questionnaire.

Data collected for the purpose of this research are presented in tables and analyzed using percentage. To determine the total sport facilities at a sport center, the following formula was used:

$\frac{\text { TSFSC }}{\text { TSFSA }} * \frac{100}{1}$

To determine the individual sport facility and additional sport facility needed in the study area, the following formula was used:

$\frac{\mathrm{SF}}{\mathrm{TSFSA}} * \frac{100}{1}$

Where: TSFSC $=$ Total sport facilities in a sport center, TSFSA=Total sport facilities in the study area, $\mathrm{SF}=$ sport facility, 100 $=$ percentage.

\section{Results}

Findings on types and numbers of sporting facilities provided at the various centers in Jos metropolis are presented in table 1.

The findings reveal that Rwang-Pam Township Stadium has more sporting facilities followed by Jos-Bukuru Mini Stadium. Other sporting centers had only few facilities, with Golf Course Lamingo having just one facility which is the golf course itself. Indicating a short fall from the required facilities required to boost sporting activities in Jos Metropolis and increase revenue generation.

\begin{tabular}{|c|c|c|c|c|c|c|}
\hline $\begin{array}{c}\text { Sport centers/ } \\
\text { facilities }\end{array}$ & $\begin{array}{c}\text { Rwang-Pam } \\
\text { Township Stadium }\end{array}$ & $\begin{array}{c}\text { Jos Bukuru } \\
\text { Mini Stadium }\end{array}$ & $\begin{array}{c}\text { Lamingo Gulf } \\
\text { Course }\end{array}$ & Plateau Club & $\begin{array}{c}\text { University of } \\
\text { Jos Stadium }\end{array}$ & Total \\
\hline Gymnasium & 1 & 1 & NA & NA & NA & 02 \\
\hline Volleyball & 3 & 1 & NA & NA & NA & 04 \\
\hline Football court & 1 & 1 & 2 & NA & 1 & 05 \\
\hline Table tennis & 1 & 1 & NA & NA & 1 & 03 \\
\hline Golf course & NA & 2 & 1 & NA & 1 & 04 \\
\hline Lawn tennis & 1 & 1 & NA & 1 & 1 & 04 \\
\hline Basketball & 2 & 1 & NA & NA & 1 & 04 \\
\hline Swimming pool & 2 & NA & NA & 1 & N/A & 03 \\
\hline Handball court & 1 & 1 & NA & 1 & N/A & 03 \\
\hline Taekwondo Ring & 1 & 1 & NA & N/A & N/A & 02 \\
\hline Total & 12 & 11 & 03 & 03 & 04 & 33 \\
\hline
\end{tabular}

Table 1: Sporting Facilities at Various Sporting Centers in Jos Metropolis

Source: Field Work, 2019

$\mathrm{NA}=$ Not Available

The results in table 1 reflect that there are thirty-three (33) sporting facilities scattered among the sport centers within the study area. These sporting facilities are unevenly distributed partly due to the age of the center, sport interest of the sport-tourists and the level of patronage. Rwang-Pam Township Stadium has 36.7\% sporting facilities, Jos Bukuru Mini Stadium has 33.3\%, Lamingo Golf Course has 9\%, Plateau Club has 9\% and University of Jos has $12 \%$. Further analysis of sporting facilities shows that football court is the highest (15.1\%) followed by volleyball, golf course and lawn tennis each having 12.1\%; table tennis, basketball, swimming pool and handball have $9.1 \%$ each while gymnasium and taekwondo ring have $6.1 \%$ each. Football court is highest because it is the most popular, interested and preferred game among the youth not only in the study area but world over.

All the sport-tourist centers in the study area are in need of additional facilities to cope with the ever-increasing demand. A total of seventy-nine (79) sport-tourism additional facilities are required. The quest for additional sport-tourism facilities is based mainly on interest and demand by the sport-tourists.

\section{Conclusion}

Aside security and conduciveness of weather, another important factor which promotes sport-tourism in a place is the availability of adequate facilities to cater for both the interest and teaming population of the sport-tourists. This 
study shows that the study area has some sporting facilities for tourist such as football court, volleyball court, swimming pool, table tennis, lawn tennis, golf course, handball, gymnasium, basketball and taekwondo. Out of the thirty-three (33) facilities available. Most of these sport-tourist facilities are found at Rwang-Pam Township Stadium. The study further revealed that a total of seventy-nine (79) additional facilities are needed with gymnasium and swimming pool taking the lead. Mountain race could also be introduced due to the hilly nature of the study area. If these additional facilities are provided, the study area would become both national and international tourist destination thereby boosting the economy of Plateau State and Nigeria at large by increasing both sources of internally generated revenue (IGR) as well as foreign exchange and less dependence on the oil sector which is a non-renewable resource while tourism is a renewable source of income.

\section{References}

i. Backman K. F. (1995): Event Tourism: An examination of motivations and activities. Festival Management and Event Tourism. 3 (1) 15 - 24.

ii. Chibuikem, A.N. (2011). Conflicts and tourism development in Nigeria. In L.O. Enukora, Akwo, J.S. and Terdoo, F. (eds). The Institute of Certified Geographers of Nigeria, Book of abstracts on conflicts and peace in Nigeria, The place of Geography. Pg. 120

iii. Dale B. (2005). Service Improvement in a Sport Environment. A study of spectators' attendance.

iv. Gammon, S. and Robinson, T. (2003). Sport and Tourism: a Conceptual Framework. Journal of Sport Tourism. 8(1):21-26.

v. Getz, D. (1998). Trends, Strategies and issues in sport - events tourism. Sport marketing quarterly 7 (2) 8 - 13.

vi. Getz, D. (1998). Trends, strategies, and issues in sport-event tourism. Sport Marketing Quarterly, 7(2), 8-13.

vii. Gibson H. (1998a). Active Sport Tourism: who participates? Leisure studies 17155 - 170

viii. Gibson, H. (1998a). Active sport tourism: Who participates? Leisure Studies, 17, 155-170.

ix. Gonap E. G., Anake C. U. and Nesla R. (2017): People's Perception of Tourist Facilities on the Jos Plateau, Nigeria. International Journal of Innovative Research and Development, Vol. 6 ( 7), 219 - 230

x. Kambayari, A. (2012). History and Development of Sports and Games for Junior Secondary Schools in Nigeria. Joson-Sam Modern Printers@Mat-Sunshine Prints, Abuja.Pg. 1.

xi. Kurtzman, J. \& Zauhar, J. (2003). A Wave in Time- The Sports Tourism Phenomena. Journal of Sport \& Tourism, 8, 35-47

xii. Managing service quality, 15, 459 - 470

xiii. Mason P. (2008) Tourism impacts planning and management (2nd ed) New York: Butterworth Heinemann.

xiv. Nigeria Tourism Development Corporation NTDC (2011); Tourist Attractions in Abuja and nearby destinations.

xv. Plateau State Tourism Corporation (1998): This is Jos.

xvi. Plateau State Tourism Corporation (2005) Tourist Attractions in Plateau State.

xvii. Ritchie, B. W. \& Adair, D. (2004). Sport Tourism: An Introduction and Overview. In B. W. Ritchie \& D. Adair (Eds.), Sport Tourism: Interrelationships, Impacts and Issues (pp.1-29). Tonawanda, NY: Channel View Publications

xviii. Ryal-Net, B.M. (2010). Characterizing cultural motleys of Kamuku National Park. The Cardinal Point. Journal of the Institute of Certified Geographers of Nigeria.2(1):22-31.

xix. Standeven, J. \& Deknop, P. (1999). Sport Tourism. Champaign. IL: Human Kinetics.

xx. World Tourism Organization. 2018Tourism Organization (2018), UNWTO Tourism Highlights, 2018 Edition, UNW 